\title{
Vote Buying, Village Elections, and Authoritarian Rule in Rural China: A Game-Theoretic Analysis
}

\author{
Hiroki Takeuchi
}

\begin{abstract}
Village elections are a democratic institution in one of the most resilient authoritarian regimes in the world. The Chinese Communist Party (CCP) has promoted village elections over the past twenty years, but not elections at higher levels. I present a game-theoretic model in which candidates would engage in vote buying when competing in a small electorate but not when competing in a larger electorate. The model's equilibrium outcome implies that the logic of China's introduction of village elections inherently limits this democratic reform to the grassroots level. Elections for higher levels of government would be dangerous to the regime because they would lead candidates to create substantive policy platforms and political organizations. Thus, rather than being an experiment that has failed to lead to further reforms, village democracy is self-limiting by design. KeYwords: China, authoritarian rule, authoritarian elections, vote buying, grassroots elections
\end{abstract}

THE TRADITIONAL VIEW OF DICTATORSHIPS FOCUSES ON THE MEANS BY which a totalitarian leadership exercises control over society; however, many authoritarian regimes actually have some democratic institutions, especially electoral and legislative systems. While scholars have often considered these democratic institutions in authoritarian regimes as harbingers of democratization in China (e.g., Chan 1998; Pei 1995; but Louie 2001) and other authoritarian countries (e.g., Mozaffar 2002; Schatz 2006; Schedler 2002), Levitsky and Way $(2002,51)$ argue that they are rarely "incomplete or transitional forms of democracy." Instead, as Magaloni and Kricheli (2010) argue, authoritarian regimes use democratic institutions to minimize the threat of potential rebellion by both the elites and the masses.

The argument that democratic institutions help authoritarian regimes survive has been made with reference to a number of developing regions. For instance, elections helped alleviate intraparty tension 
over personnel management of party officials in authoritarian regimes in Latin American countries such as Brazil and Argentina (Geddes 2006). In Mexico, the authoritarian party discouraged potential opposition powers from cooperating with each other by winning the overwhelming majority in elections (Magaloni 2006). The authoritarian regime has constrained, split, and co-opted the opposition through elections in the Middle East as well (Lust-Okar 2005). And in Egypt, authoritarian elections have helped the regime decide how to distribute rents and even public goods (Blaydes 2010). What is common in these examples is that democratic institutions strengthen the ruling party while deterring the formation and growth of opposition parties, and authoritarian rulers systematically establish and maintain electoral systems and other institutions for those purposes (Gandhi and Przeworski 2006).

The institutional development of village elections in China is an excellent case for examining how democratic institutions affect the stability of authoritarian rule. China's authoritarian regime has allowed, encouraged, and required that elections be held at the village level, but not at higher levels. China's village elections have acquired special attention in light of the limited political reforms introduced during the last three decades of the post-Mao era. China's authoritarian regime hoped that the village elections would improve local governance in its vast countryside - where the majority of the Chinese population continues to reside even after large-scale migration from rural to urban areas - by disciplining local officials and preventing massive rural unrest (Li 2003; Li and O'Brien 1999; Shi 1999). Some empirical findings suggest the positive effects the regime hoped for: villages with elected cadres are more likely to have leaders who are receptive to popular preferences (Alpermann 2001; Kennedy, Rozelle, and Shi 2004; Manion 1996, 2006), and the implementation of village elections has arguably reduced the likelihood of mass uprising ( $\mathrm{Li} 2001$; O'Brien and Li 2001; Pastor and Tan 2001; Schubert and Chen 2007).

I use a formal model to explore the political effects of village elections in rural China. The model outlines a logic that shows how introducing elections at the grassroots level is consistent with the survival strategy of the authoritarian regime. A crucial component of the argument has to do with scale. The model's equilibrium shows the probability that a vote-buying candidate will win an election increases as the size of the electorate decreases. In other words, electoral competition at the local level gives strong incentives for candidates to buy votes rather than to form an organization for mobilizing votes. As a 
result, local elections can work to deter organized challenges and thus stabilize and strengthen the Chinese authoritarian regime.

The findings have implications for the debate over the role local elections might play in political reform in China, including the issue of electoral corruption. Tocqueville ([1835 and 1840] 2000) praised grassroots elections as deserving principal credit for the effective democratic government of the United States in the early nineteenth century. However, after Tocqueville left America, grassroots politics became less important, elections at higher levels became more important, major mass parties developed, and the two-party system was established by the 1860s (Aldrich 1995, chap. 5). Moreover, studies on electoral institutions have found that grassroots elections are prone to corruption, because small-sized electorates tend to vote based on personal patronage. For example, Cox (1987, 169-170) finds that there had been "a sizable personal vote in the constituencies" in the British parliamentary elections until the mid-nineteenth century and that "the politics of avoiding or of winning a contest often involved reliance on influence, patronage, and bribery." Interestingly, though, candidates started stressing policy in their electoral campaigns in the late nineteenth century when they had to appeal to the larger electorate that developed with the extension of suffrage. Moreover, Kousser (1974) argues that in the post-Civil War American South, restrictions on African Americans' suffrage made candidates rely on personal patronage from small-sized constituencies and caused the one-party rule of the Southern states.

The evidence seems to suggest that it is inevitable for grassroots elections to be corrupt, but a survey of elections in rural China reveals that some village elections are corrupt and others are not. ${ }^{1}$ Vote buying is more prevalent as races are more competitive, which is not surprising. But this finding also correlates with an interesting observation about local elections. During official enforcement of electoral contestation, a pattern of "consensual elections" has emerged in the Chinese countryside in which villagers reach a consensus on certain competent candidates before the election. These candidates are elected in a contested but noncompetitive election, but voters nevertheless feel satisfied with the electoral outcome and the elected representatives, perhaps in part because vote buying under these circumstances is less prevalent. In the meantime, in the villages that have failed to reach a preelectoral consensus, elections are competitive but also corrupt.

In sum, based on assumptions that incorporate the institutional setting of village politics and the characteristics of the village 
community in China, the model's equilibrium derives the following implications:

1. Once the size of the electorate reaches a certain level, vote buying becomes a costly strategy to win an election, hence candidates rely more on electoral campaigns that stress their policy proposals and appeal to the larger electorate with relatively low costs.

2. Conversely, the probability that a vote-buying candidate will win an election increases as the size of the electorate decreases.

3. Corruption is not an inevitable feature of local elections. Vote buying is more prevalent when elections are more competitive. If voters have a consensus on which candidate they will elect, and one candidate is significantly stronger than another candidate, then the probability that a vote-buying candidate will win is lower. In other words, elections are more likely to be clean if voters have reached a preelectoral consensus on whom to vote for, which may deter vote buying in grassroots elections.

I begin the article by identifying the institutions of China's village elections and their unique characteristics. ${ }^{2}$ I then discuss the game-theoretic model and the logic the model's equilibrium implies. In the third section I introduce examples of how a preelectoral consensus may be formed and vote buying prevented in China's village elections. I conclude the article by discussing the model's implications for the resilience of the authoritarian regime and possible paths to wider democratization in China.

\section{Competition and Corruption in China's Village Elections}

In 1980, eighty-five peasant households in Hezhai Village, Guangxi Province participated in a landmark event: the first popular election for a villagers' committee (VC) in China. The Chinese government institutionalized the elections of VC members with the Organic Law of Villagers' Committees (hereafter the Organic Law) in 1988. The Organic Law was revised in 1998 to include a specific clause regarding the nomination process: Article 14 of the revised Organic Law specified that each election ought to be contested. A contested election is 
one in which the number of candidates exceeds the number of seats available. Since 1998, contested village elections have spread throughout China. However, contested elections are not always competitive. A competitive election is one in which the race between candidates is so close that one cannot easily predict who will win. In rural China, as well as in other countries, some elections are competitive and others are not.

Among the many features that characterize China's village elections, two factors in particular make this electoral institution unique. First, even though the Organic Law stipulates that the elected VC is the village's highest decisionmaking organization, the nonelected village party branch (VPB) is apparently more powerful and influential in village politics than the VC. These two organizations are vested with the authority to make policy decisions in every Chinese village. However, the VPB is often at an advantage over the VC because the township government - the superior authority of the village-supports the VPB as part of the CCP's vertical organization. Moreover, the implementation of village elections may be difficult as it "often involves a struggle between villagers who demand improved accountability and township leaders who, initially at least, refuse to cede their authority to appoint village cadres" ( $\mathrm{Li}$ and O'Brien 1999, 143). Nonelected party officials at the township and county levels have many opportunities to use a strategy of "feigned compliance" to resist holding village elections (Kelliher 1997, 84). Furthermore, there are reported cases of a CCP-supported candidate's failing to be elected and nonelected township officials subsequently declaring that the nonelected CCP cadres should be in charge of all administrative responsibilities, with the elected cadres simply empowered to follow the CCP cadres' decisions (Liu 2000). Thus, Kennedy (2009) argues that a key to a successful village election is removing township officials from the process of electing village leaders.

Second, the unique characteristics of the village community influence voters' behavior, candidates' strategies, and electoral outcomes. For example, when interviewing the vice-secretary of Rose Town in Hunan Province, who was responsible for monitoring the implementation of village elections in his town, I asked, "How do candidates conduct a campaign during the village election?" $\mathrm{He}$ proudly responded, "Candidates in the village elections in our town never carry on a campaign. So we don't have a problem of 'buying votes.' No campaign, no corruption" (Interviewee 53, township official: Hunan, March 2005). His answer was interesting, because he 
assumed that campaigning and vote buying should be closely related, and hence if there were campaigning, the elections would be tainted by corruption.

Here is another example. When interviewing the VC chief of East Gate Village in Hebei Province, I asked, "How was the last election for you? How did you appeal to villagers during the election?" He answered, "I did nothing during the last election. I felt that I did not have to be VC chief as I had already been village party secretary. But villagers nominated me for candidacy and I was elected" (Interviewee 20, village cadre: Hebei, January 2005). Again, his answer is interesting, because under normal circumstances if a candidate does nothing, he or she will usually lose the election, but in fact, he thought there was no need to campaign at all. Two villagers said that they were satisfied with his job when he was village party secretary and thus they had no reason to nominate someone else as a candidate for VC chief (Interviewees 28-29, villagers: Hebei, January 2005). Institutionally, candidates in village elections do not decide to run but are nominated by villagers, village cadres (especially VPB cadres), or township cadres (Kennedy 2002).

These two anecdotes suggest that those who are involved in village elections perceive that a campaign is not necessary to win an election. A Chinese village is a small enough community for each villager to know all the other villagers in person as they interact with each other on a daily basis. This not only applies to Water Dragon Village in Guangdong Province, a small village with a population of 309, but also to Bird Town Village in Hebei Province, a large village with a population of over 5,000. In Bird Town Village, I asked three villagers whether they know everyone in their village. They all responded along the lines of, "Yes, I know everyone. Of course, I know some of them better than others, and I'm not familiar with some of the villagers, but I can recognize all the villagers. We usually go to the same elementary school if we live in the same hamlet and all the villagers go to the same junior high school" (Interviewees 35-37, villagers: Hebei, April 2005). In a Chinese village, it is rare for someone to immigrate from outside the village; thus, it is easy to maintain affinities formed during the school period.

The fact that residents in the community know each other highlights a significant difference between grassroots elections such as China's village elections and an election with a large electorate. In a grassroots election, it is easy for voters to acquire personal information about the candidates. Thus, policy proposals that candidates make in 
their campaigns will not change voters' information about the candidates. Therefore, in a small electorate, campaigning is not an effective strategy to win an election.

In contrast, vote buying can easily be an effective means to win an election in a small electorate. ${ }^{4}$ First, the number of votes needed to win, and hence the number of votes a candidate needs to buy, will ceteris paribus be smaller as the electorate is smaller. In other words, vote buying is more likely to be crucial for the electoral outcome in grassroots elections (Lehoucq 2003). Second, and more importantly, being in a small community makes it easier for a candidate to determine what each voter personally wants, thus candidates can promise their favored voters the provision of private goods that will exclusively benefit them, instead of promising the provision of public goods that will benefit the whole electorate. ${ }^{5}$ Third, in a small village community, candidates' promises to provide private goods are deemed credible once they show their intention and ability to give personal favors because they will face social sanctions through their daily interactions with villagers if they do not keep their promises. In other words, the norm of reciprocity is more easily enforced in a small electorate (Stokes 2007). By contrast, in an election with a large electorate, elected leaders will face electoral sanctions by failing to be reelected if they do not fulfill their pledges after election. In this way, candidates are forced to make policy pledges during the electoral campaigns, to which candidates and elected leaders will be held accountable by the electorate.

It is not puzzling, then, that candidates compete to buy votes by promising private goods in campaigns for China's village electionsand generally in grassroots elections. However, competition for vote buying does not always occur. In some cases, elected cadres succeed in their efforts to provide public goods and voters feel satisfied with these representatives. Because it is easy for both candidates and voters to acquire personal information about each other, reaching a consensus on electing certain competent candidates is simpler in a small electorate. Whether a grassroots election is consensual or competitive depends on whether the elites are competent and intend to provide public goods.

\section{The Model of China's Village Elections}

I make two arguments. First, as the size of an electorate increases, the cost of vote buying increases as well. When the cost of vote buying 
goes up, candidates must turn to different mechanisms for appealing to voters, namely, organization-based, programmatic campaigns. The main inference to be drawn from this argument is that the CCP prefers grassroots elections because it would like to discourage organized opposition. Second, grassroots elections are not necessarily corrupt and there is variance in the level of corruption. However, corruption is less likely only when elections are less competitive. Therefore, ironically, there is a trade-off between competitiveness and corruption in grassroots elections. The collection of the data discussed in this article is constrained by the limited sources that systematically report the processes and outcomes of village elections. Thus, this section develops a game-theoretic analysis to provide systematic logic to account for the two major arguments. A formal description of the model is presented in the Appendix.

\section{The Candidate's Choice of Strategies and Payoffs}

Suppose that there are two candidates and they must choose their strategies to gain election without knowing what strategy the other candidate will take. Both candidates seek to win the election, and how much the candidate would gain from being in office varies by village. However, the value of winning an election does not increase with the electorate size while the cost of buying votes to win does. One might imagine that a leader in a larger village can extract much greater rents (as well as prestige, job satisfaction, and so on) from his or her job than a leader in a smaller village can. The major reason the model assumes that the value of winning is independent of the electorate size is that rents are not related to the electorate size but to economic size. In other words, even in a small village, rents will be greater if it is an industrialized village.

To incorporate the size of the population in authoritarian politics, I set up a model similar to that of Bueno de Mesquita et al. (2003). Their model implies that political leaders who oversee smaller "selectorates" invest less in public goods and more in private goods, because private goods are divided by a smaller number of people if selectorates are smaller (Bueno de Mesquita et al. 2003, chap. 3). Under the condition of a small electorate in a Chinese village community, where voters and candidates know each other in person and interact on a daily basis, candidates are encouraged to compete to provide private goods (which is indistinguishable from vote buying in my model), not only because the number of recipients of private goods is small but also because candidates have perfect information 
on what private goods each voter wants. However, in a large electorate, where voters and candidates do not know each other in person, electoral competition will encourage candidates to campaign to a larger constituency. In order to appeal to a larger constituency, candidates will organize their efforts to mobilize voters, and the formation of a party will be an effective strategy for winning an election. The formation of an opposition party is the worst scenario for an authoritarian party - a scenario the authoritarian party would try to avoid by every possible means.

The model assumes that if one candidate buys votes while the other candidate does not, the candidate that has bought votes will win. Moreover, the cost of buying votes to win is higher as the candidate is weaker. If both candidates adopt the same strategy, Candidate 1 will have a chance to win the election with the probability of $p$ and Candidate 2 will have a chance to win the election with the probability of 1 $-p$. Because one can define the competitiveness of an election as the difficulty with which one can predict who will win, the election whose value of $p$ is closer to 0.5 will be considered more competitive. This exogenously fixed probability of $p$ captures one candidate's "valence" advantage, which may be given by "incumbency, greater campaign funds, better name recognition, superior charisma, superior intelligence, and so on" in American politics (Groseclose 2001, 862). Meanwhile, the valence advantage is given by the resources that village elites possess, such as political authority, economic resources, and social networks in Chinese village politics.

Moreover, the model takes the cost of vote buying as fixed and independent of the other player's level of vote buying. Or, more precisely, if both players choose to buy votes, then the number of votes each candidate buys does not matter because the election will be determined by $p$ - the same outcome as if neither candidate spends any money to buy votes. With this setup, the model can avoid the additional complexity of the strategic choice of coalition members, while maintaining the assumption that each player knows that the other player may also buy votes.

\section{Solution to the Model}

The intuition behind the strategies taken at equilibrium is straightforward. In the villages where each candidate's expected value of winning an election is high, each candidate is tempted to buy votes. While both candidates will buy votes if the expected value for winning is very high, neither candidate will buy votes if the expected 
value is very low. In general, the probability that either or both candidates will buy votes will be higher and approach 1.0 as the expected value for winning an election increases. However, the reason candidates will buy votes is somewhat different depending on the circumstances.

When the expected value for winning an election is very high, both candidates will buy votes. In the elections where candidates will always buy votes, the game takes the form of a prisoner's dilemma. In the prisoner's dilemma, each player's rational strategy to maximize his or her individual payoff ends up with a worse outcome than some other possible outcome that may be better for both players. In the game of China's village elections with a high expected payoff from winning, each candidate will buy votes to maximize his or her payoff; however, the possible outcome that neither buys votes will be a better outcome for both candidates than the outcome that both candidates buy votes. Both candidates will buy votes because they will do better to buy votes regardless of whether the other candidate buys votes. If the other candidate does not buy votes, it will be better to buy votes and win the election, taking advantage of the other candidate's noncorrupt practice. If the other candidate buys votes, it will still be better to buy votes and keep the chance of winning the election at $p$ for Candidate 1 and $1-p$ for Candidate 2; otherwise, the candidate that buys votes will win the election for sure. Both will use this reasoning and will take the same strategy of buying votes.

However, grassroots elections are not always corrupt. Once the expected value of winning an election is lower than a certain threshold, the weaker candidate will stop buying votes while the stronger candidate will keep buying votes. The stronger candidate knows that he or she will be more likely to win once he or she chooses the strategy of buying votes, even if the weaker candidate also chooses the strategy of buying votes. If the weaker candidate does not buy votes, the stronger candidate will still find buying votes to be a better strategy to ensure certain victory. Thus, the stronger candidate has an incentive to buy votes regardless of the strategy the weaker candidate takes. For the weaker candidate, by contrast, the expected value of winning an election is not high enough to keep the probability of winning at $p$ by buying votes, given that the other candidate will buy votes. Therefore, the weaker candidate will not take the strategy of buying votes under this condition.

If the expected value for winning an election is even lower, the stronger candidate will not always have an incentive to buy votes. Instead he or she will prefer not to buy votes if the other candidate 
does not take the strategy of buying votes, because buying votes is costly relative to the expected value of winning, even for the stronger candidate. Conversely, the weaker candidate will have an incentive to take the strategy of buying votes if and only if the stronger candidate does not buy votes. Thus, for each candidate, the best strategy depends on the strategy the other candidate takes. Moreover, both candidates have an incentive not to let the other candidate know which strategy he or she will take. With this logic, each candidate may buy votes with a certain probability but will not always buy votes. Both candidates will take one strategy with a certain probability and the other strategy with another certain probability.

When the expected value of winning an election is very low, neither candidate will buy votes. The cost to buy votes is so high for both candidates, relative to the benefit from winning an election, that neither candidate will have an incentive to buy votes whatever strategy the other candidate takes.

\section{Competition in a Grassroots Election}

Would electoral competition prevent a vote-buying candidate from being elected? The extent to which the election is competitive can be modeled as the value of $p$ approaches 0.5 . To examine how changes in certain parameters would affect the equilibrium, I offer a numerical example. Figure 1 shows how the probability of having a votebuying winner depends on the extent of electoral competition $(p)$ and the expected value of winning an election $(W)$.

When $W$ is small, no candidate takes the strategy of buying votes however competitive the election is, and the winning candidate is not a vote-buying one. However, after $W$ exceeds a certain threshold, at least one candidate has an incentive to buy votes with a certain probability, and a winner may be a vote-buying candidate. This threshold is reached more quickly as the election becomes less competitive. When $W$ is small, the cost of buying votes is high enough, compared to the gain from winning an election, to prevent both candidates from buying votes. However, as an election becomes less competitive, the weaker candidate's expected payoff from not buying votes while the stronger candidate does not buy votes is lower. Thus, the weaker candidate will have more of an incentive to buy votes. Knowing that the weaker candidate will have more of an incentive to buy votes, the stronger candidate will also have more of an incentive to buy votes.

Interestingly, after $W$ exceeds the threshold, as long as $W$ is smaller than 0.78 , the probability of a vote-buying candidate's win 
Figure 1 Probability of a Vote-buying Candidate's Win for Different Thresholds of Electoral Competition

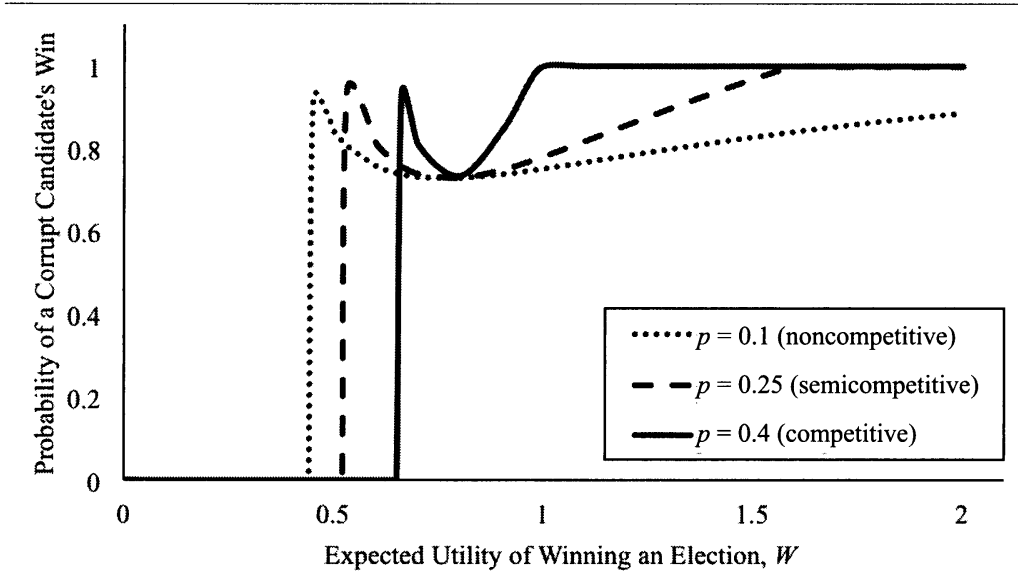

Note: $\beta=0.05, \varphi=0.2, A=5$, and $E=1.5$.

decreases as $W$ increases. As $W$ increases, each candidate primarily has more of an incentive to buy votes to win an election. However, the weaker candidate will prefer the strategy of not buying votes if the stronger candidate buys votes. Moreover, if the weaker candidate does not buy votes, then the stronger candidate will prefer to not buy votes. Thus, both candidates face the dilemma that the condition that gives them an incentive to buy votes will also give them an incentive to not buy votes. Through this strategic interaction, a larger value of $W$ will lower the probability of a vote-buying candidate's win.

However, once $W$ exceeds 0.78 , the incentives for the candidates are more straightforward. A higher value of $W$ will give the stronger candidate more of an incentive to ensure victory by buying votes. In a certain range, the stronger candidate will still prefer to not buy votes if he or she is not sure whether the weaker candidate will buy votes. However, as $W$ is larger, the stronger candidate will be more threatened by the weaker candidate's strategy to buy votes, and the stronger candidate will have more of an incentive to ensure victory by buying votes as the election becomes more competitive. Hence, the election will have a vote-buying winner because the stronger candidate will buy votes and be elected. Therefore, the probability of a vote-buying candidate's win is higher as the election becomes more competitive. In other words, although grassroots elections are not necessarily corrupt, corruption will be more likely if elections are more competitive. 


\section{The Size of the Electorate}

How would the size of the electorate affect candidates' vote-buying behavior? Figure 2 examines how the probability of a vote-buying candidate's win depends on the size of the electorate $(E)$ and the extent of electoral competition $(p)$. Overall, an increasing $E$ would decrease the probability that a vote-buying candidate would win. Moreover, electoral competition would make it more likely for a vote-buying candidate to win in a small electorate, while it might make it less likely for a vote-buying candidate to win in a large electorate because candidates will have to turn to mechanisms other than vote buying if the cost of vote buying is higher due to the large electorate size.

If $E$ is small, candidates will always buy votes however competitive the election is. However, an increasing $E$ would increase the cost to provide private goods, and at a certain threshold the weaker candidate would stop buying votes. Moreover, if $E$ is even larger and exceeds this threshold, then the stronger candidate might also stop buying votes and the probability of a vote-buying candidate's win would be less than 1.0. The value of this threshold is smaller as the election becomes less competitive. After $E$ exceeds the threshold, as long as $E$ is smaller than 2.5 , the probability of a vote-buying candidate's win decreases as $E$ increases. After $E$ exceeds 2.5 , the probability of a vote-buying winner increases as the size of the electorate increases. However, once $E$ reaches a certain threshold, no candidate buys votes

Figure 2 Probability of a Vote-buying Candidate's Win Depending on the Electorate's Size

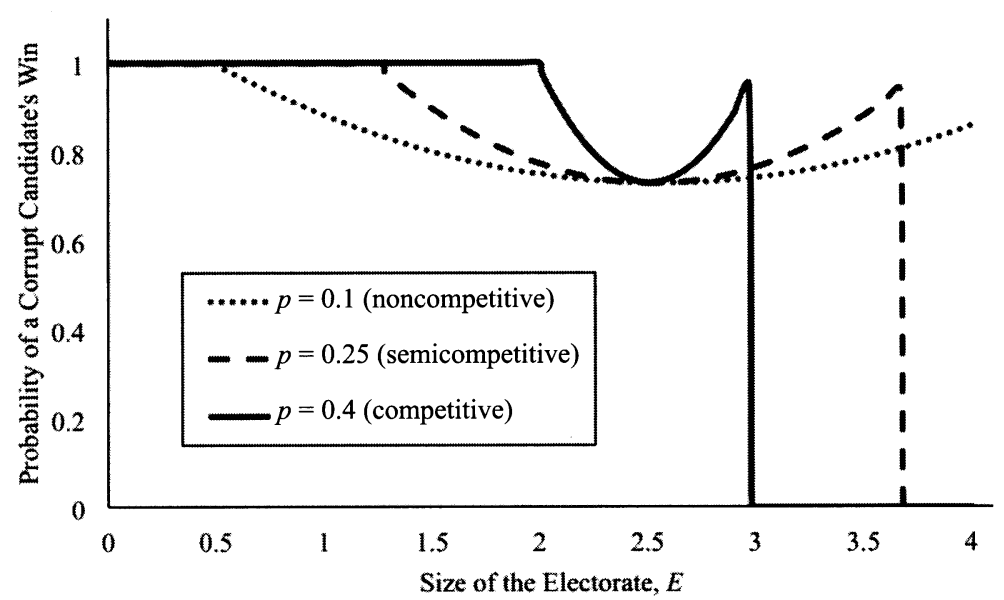

Note: $\beta=0.05, \varphi=0.2, A=5$, and $W=1.3$. 
and the probability of a corrupt candidate's win is zero. The value of this threshold is smaller as the election becomes more competitive.

When the electorate is small, the cost to provide private goods is low, and hence both candidates have an incentive to buy votes regardless of the other candidate's strategy. However, as the size of the electorate increases, the cost of buying votes also increases, especially for the weaker candidate. The cost of buying votes for the weaker candidate would increase more steeply along with the increase in the size of the electorate as an election becomes less competitive. Once the weaker candidate's strategy deviates from vote buying, in the new equilibrium both candidates will prefer the strategy of not buying votes if the other candidate does not buy votes. Thus, in this range, a non-vote-buying candidate wins an election with a certain probability, and the increasing size of the electorate will lower the probability of a vote-buying candidate's win. However, once $E>2.5$, the probability of a vote-buying winner increases along with the increase in $E$ in a certain range, where the stronger candidate will have more of an incentive to buy votes to ensure victory in case the weaker candidate buys votes to challenge the stronger candidate's advantage. This range becomes larger as an election becomes less competitive, because the stronger candidate's cost of buying votes is lower as $p$ becomes lower. Once the size of the electorate is above this threshold, both candidates will find buying votes so costly that neither candidate will buy votes regardless of the other candidate's strategy.

\section{Summary}

The game-theoretic model suggests that electoral competition would increase the probability of a vote-buying candidate's win in a small electorate while it might decrease the probability of vote buying in a large electorate. This is because when the electorate size goes up, the cost of vote buying goes up as well and candidates would have to turn to different mechanisms for appealing to voters such as policy-based, organized campaigning. Moreover, grassroots elections are not always corrupt. If there is preelectoral consensus on which candidate to vote for, then it would prevent a vote-buying candidate from winning in a small electorate. Thus, there is a trade-off between competitiveness and corruption in grassroots elections with small electorates.

\section{Consensual Elections and Rural Elites}

How does one candidate emerge as the consensus preference before an election? The game-theoretic model discussed in the previous section 
suggests that whether the village has a candidate on whom villagers can reach a consensus is a key determinant of whether the winner is corrupt or accountable in a grassroots election. In other words, making the election less competitive makes a grassroots election less corrupt. Most of the studies on China's village elections look at the electoral process and the postelection outcomes but few examine the preelection process. I argue that the roles elites play in villages are key to whether electoral consensus may emerge and vote buying may be deterred in the village.

I define three types of elites in rural China: political, economic, and social. They are, respectively, members of the CCP, entrepreneurs in rural industry, and leaders of kinship groups. They have the ability to provide public goods based on the resources they have, such as political authority, economic resources, and social networks. Due to these resources, their commitment to provide public goods would be credible if they have the intention to serve the whole village. I define consensual elections as those in which (1) voters reach preelectoral consensus on which candidate(s) to vote for; (2) the elections are not competitive although they are contested; and (3) voters are satisfied with the performance of the elected VCs.

\section{Political Elites}

One of the important (and controversial) institutional features of village elections in rural China is that candidates do not make the decision to run by themselves but are nominated by villagers, village cadres, or township cadres. Tan (2009) argues that under this rule someone who does not intend to serve the villagers may be elected as a VC cadre. The rule allowing villagers to nominate candidates is also viewed as a way to prevent party officials from intervening in electoral results. However, Kennedy (2002) observes that in the thirty-four villages of Shaanxi Province he studied, villagers tend to be satisfied with the electoral process and results when the VPB nominates candidates. Many cases demonstrate that the VPB nominates and supports non-CCP members. To cite an example from my field interviews, in Water Dragon Village, a wealthy industrialized village in Guangdong Province, the VPB supported incumbent Mr. Ye in the 2002 election, testifying to his ability to promote industrialization of the village even though he was not a CCP member (Interviewee 1, village cadre: Guangdong, December 2004). This observation is puzzling, because VPB members are not popularly elected and they do not always have an incentive to nominate candidates the villagers would nominate or support. 
The concept of consensual elections may provide an explanation. Suppose that the village party secretary intends to serve the whole village. This cadre has a strong incentive to nominate a candidate with the ability and intention to provide public goods. An election will not be competitive but consensual because villagers can reach preelectoral consensus to elect the VPB-nominated candidate. Moreover, villagers will be satisfied with the electoral process and result because they know that the VPB-nominated candidate has the ability and intention to provide public goods. A key aspect of this scenario is that the village already has a village party secretary who intends to serve the whole village. As long as the village party secretary has such an intention, villagers know he or she will nominate a competent leader with the intention and ability to provide public goods. As a result, we would expect to observe that the village has a consensual election and that the elected VC provides public goods.

However, the VPB does not always nominate a competent candidate. When VPB cadres are corrupt, they nominate their own members for village elections. Then, if a villager-nominated candidate beats a VPB-nominated candidate, VPB cadres attempt to nullify the elected VC members' authority. Often the township government backs up the VPB's attempt because township officials also benefit from the VPB's corrupt practice. For example, in Wugezhuang Village of Shandong Province, after the village party secretary was defeated in the 2002 election, the township government declared that the VPB should be in charge of all administrative responsibilities and the VC should simply follow the VPB's decisions (Xu 2004, 38). Then, the VPB cadres ignored the interests of the majority of villagers and made decisions in favor of those with whom they had special personal relations when they decided on land expropriation - an issue in which villagers had high stakes.

The example of Wugezhuang Village demonstrates the limitations of village elections in rural China for holding cadres and officials accountable to the electorate. The comparison of Wugezhuang Village with Water Dragon Village suggests that the elected VC will provide public goods if and only if nonelected VPB cadres have the intention to serve the whole village. It suggests that electoral contestation itself will not give cadres and officials an additional incentive to provide public goods.

\section{Economic Elites}

In many industrialized wealthy villages, often located in the coastal regions, entrepreneurs have become $\mathrm{VC}$ chief when they win a village 
election, and become village party secretary when they obtain membership in the CCP. In the following examples, the election of entrepreneurs was consensual. Villagers see entrepreneurs' success in business and expect them to use their wealth to provide public goods. Entrepreneurs' wealth makes their commitment to the provision of public goods credible.

There are several examples of entrepreneurs' election to VC membership through consensual elections, subsequent provision of public goods, and villager satisfaction with the processes and results of elections. In the 2002 Huaxi Village election in Zhejiang Province, $\mathrm{Mr}$. Yu promised to contribute 100,000 yuan out of his own pocket80,000 yuan to clean up the village and 20,000 yuan in donation to the village's senior association (Lang 2003, 191-192). In another example from the 2002 Zhejiang village elections, in Shangyang Village Mr. Yang promised to spend 100,000 yuan out of his own pocket toward payment of the agricultural tax to the town government so that villagers would not have to pay it, and to donate his three-year salary to the village's senior association (Lang 2003, 192). In Fuyang Village of Zhejiang Province, a wealthy village with a per capita income of 6,000 yuan in 2001, no one ran against incumbent Mr. Zhou in the 2002 village election (Lang 2003, 188-190). If competition is the criterion for success of an election, this election was a failure. However, if the criterion for a successful election is whether the elected village cadre provides public goods-or more generally is committed to good governance-this election was successful. Mr. Zhou was a successful entrepreneur and served as a village cadre for more than twenty years. Villagers knew how he worked as a village cadre, and more importantly, they knew that he had sufficient financial resources to provide public goods.

In another example of an entrepreneur's competent village leadership, in Highland Park Village of Zhejiang Province, villagers elected Mr. Shi, a then thirty-six-year-old entrepreneur managing a successful apparel factory, to be VC chief in 1995 (Interviewee 103, county official; 104-105, village cadres: Zhejiang, December 2004). Originally, Highland Park Village was not as wealthy as surrounding affluent villages because of its unfavorable geographic conditions. However, since Mr. Shi became VC chief, he has used his entrepreneurial talent to provide public goods. First, the VC invested in infrastructure to attract factories to the village and produced many employment opportunities for villagers. Then, those factories paid corporate taxes to the village, so the village offices (VC and VPB) had sufficient revenue for the provision of public goods. Now, Highland Park 
Village is one of the wealthiest villages in Zhejiang, which is the province with the highest rural per capita income in the nation.

By contrast, in Chishi Village, a poor village in Inner Mongolia Province, villagers elected someone "clean" to be VC chief to curb existing corruption. The elected VC chief promised to reveal the village party secretary's embezzlement (Ako 2003). However, because incumbent VPB cadres were corrupt and the VPB was more powerful than the $\mathrm{VC}$, the elected $\mathrm{VC}$ chief was not powerful enough to check the VPB cadres' corruption. Elected VC members gave up holding them accountable to the electorate. To make matters worse, the elected $\mathrm{VC}$ chief joined the corrupt practice of the nonelected VPB members and enjoyed the benefits of embezzlement.

The comparison of the industrialized villages in Zhejiang Province to Chishi Village suggests how differences in economic status may influence the relationship between the VC and the VPB. In industrialized villages the leadership of an entrepreneur can start a virtuous circle for providing public goods while elections are not competitive but consensual. Successful entrepreneurs may bring prosperity to the village by using their own wealth to provide public goods. Once an entrepreneur intends to be a competent leader for the whole village, an election will be consensual because an entrepreneur is an attractive candidate for the whole electorate, and public goods will be provided in the village. By contrast, in agricultural villages, which usually do not have entrepreneurs, villagers often cannot find candidates attractive to the whole electorate and hence an election will not be consensual but competitive. Because agricultural villages do not have sufficient financial resources to provide public goods for the whole village, incumbent village cadres have an incentive to distribute scarce financial resources to their favorite group of villagers. Candidates in a competitive election will then compete for vote buying.

\section{Social Elites}

Kinship is an important element in people's daily lives, society, and politics in rural China. Previous studies have found that kinship groups in a village are often in conflict with each other and hence villages with multiple kinship groups tend to have worse village governance performance. For example, Tsai (2007) finds that villages with multiple lineage groups are less likely to provide public goods than villages with a single lineage group. Moreover, competitive village elections worsen the conflict between kinship groups. For example, Kennedy (2002, 479-482) observes that villagers are less likely 
to be satisfied with the electoral process in multisurname villages than in single-surname villages. Furthermore, Manion (2006) finds that between 1990 and 1996, villages with more surnames ceteris paribus tended to have increased public trust in local leaders. Her logic to account for this finding is that villages with a few clans experience more intense clan-based politics than villages with numerous clans. ${ }^{6}$

In some villages, elections have indeed exacerbated kinship rivalries. For example, in one of the villages that Kennedy $(2002,480)$ studied in Shaanxi Province, there was a long history of conflict between two major kinship groups, but the balance of power was maintained by assigning the village party secretary from one group and the $\mathrm{VC}$ chief from the other group. However, in the first contested election for $\mathrm{VC}$ chief, each group nominated a candidate, the election was intensely competitive, and the candidate from the same group as the village party secretary won the election. The elected VC chief used his status to enrich his own group, and members of the other group were dissatisfied with the electoral process and outcome.

In other villages, however, kinship politics have had positive effects on elections. For example, in You Village of Jiangxi Province, like the village discussed above, the balance of power was maintained by assigning the village party secretary from one kinship group and the VC chief from the other group, before the first contested election in 1999 (Tong 2004, chap. 2). In the 1999 election, just as in the election of the village discussed by Kennedy above, each group nominated a candidate, the election was intensely competitive, and the candidate from the same group as village party secretary won the election. However, the subsequent process was different in You Village. Concerned that the electoral result might create a monopoly of power by a certain kinship group, the party secretary of Niuxi Township, which You Village belongs to, intervened in the electoral process. After discussing the matter with village cadres and kinship leaders, the township party secretary decided to hold the election again, referring to the fact that the winner did not have a majority if invalid ballots were included. The reelection was scheduled for four days later and kinship leaders vigorously discussed the issue. The kinship leaders agreed that the VC chief should be from the kinship group other than the village party secretary's group, so that the balance of power between kinship groups would be maintained. They persuaded members of their kinship groups to vote for the candidate they agreed to elect. Thus, the reelection was not intensely competitive 
but consensual, a candidate from the group other than the village party secretary's group was elected, and villagers were satisfied with the electoral result.

In sum, the cases discussed here suggest that if kinship leaders are in conflict, an election will tend to be competitive and corrupt, and public goods will ultimately not be provided. By contrast, if relations between kinship leaders are cooperative, an election will tend to be consensual and clean, and public goods ultimately will be provided.

\section{Generalization of the Argument}

From the cases discussed above, we may draw the following argument. First, whether the nature of an election is consensual or competitive depends on the distribution of elite competence and intention. In villages with competent elites who intend to provide public goods, a village's small size will lead to a consensual election. Meanwhile, in villages without competent elites who intend to provide public goods, an election will be competitive. As a result, village elections are not necessarily corrupt, but corruption is less likely only when elections are less competitive. Second, competitive elections will be prone to vote buying due to the village's small size. The cost of vote buying will be small if the size of the electorate is small. Thus, candidates will choose a vote-buying strategy to appeal to voters if an election is competitive and will not have an incentive to choose programmatic campaigning. Therefore, one can infer that the $\mathrm{CCP}$ can discourage programmatic opposition by introducing village elections. While these arguments are drawn from anecdotal case study evidence based on examples from particular villages, to what extent can we generalize these arguments?

I studied sixty-two cases, mostly from secondary literature (chiefly Chinese-language sources) and partly from my field research, and examined how the above arguments fare with these cases. Table 1 shows the list of village elections included in the study. Among the sixtytwo cases, thirty-four are from Jiangxi Province while the other twenty-eight are from eleven other provinces. Forty of the elections were held in 1999. In many villages, the 1999 elections were the first to be contested, according to the revised Organic Law implemented in 1998 that required every election to be contested. I included only cases for which I could find information about both the nature of the election and the provision of public goods (or lack thereof). There are many reports on village elections, but the reports that include information on both of these topics are limited. 
Table 1 The List of the Cases of Village Elections

\begin{tabular}{|c|c|c|c|c|c|c|c|}
\hline $\begin{array}{l}\text { Case } \\
\text { Number }\end{array}$ & Village & Province & Economy $^{\mathrm{a}}$ & $\begin{array}{l}\text { Year of } \\
\text { Election }\end{array}$ & $\begin{array}{l}\text { Nature of } \\
\text { Election }\end{array}$ & Elite & $\begin{array}{l}\text { Public } \\
\text { Goods }\end{array}$ \\
\hline 1 & $\mathrm{Ai}$ & Jiangxi & A & 1999 & Consensual & Political/social & Yes \\
\hline 2 & $\mathrm{Cao}$ & Jiangxi & A & 1999 & Noncompetitive & Social & No \\
\hline 3 & Chengfang & Jiangxi & A & 1999 & Noncompetitive & None & No \\
\hline 4 & Chishi & Inner Mongolia & A & 2000 & Competitive & Political & No \\
\hline 5 & $\mathrm{De}$ & Inner Mongolia & A & 2000 & Consensual & Political & Yes \\
\hline 6 & Dong & Jiangxi & A & 1999 & Noncompetitive & Political & No \\
\hline 7 & East Gate & Hebei & A & 2003 & Consensual & Political & Yes \\
\hline 8 & Fuyang & Zhejiang & I & 2002 & Consensual & Economic & Yes \\
\hline 9 & Gaoping & Jiangxi & A & 1999 & Competitive & Political/social & No \\
\hline 10 & Guan & Jiangxi & $\mathrm{A}$ & 1996 & Competitive & Political & No \\
\hline 11 & Guobaozhuang & Shandong & A & 2001 & Competitive & Political & No \\
\hline 12 & Guowa & Jiangxi & A & 1999 & Competitive & Social & No \\
\hline 13 & Guozhuang & Shandong & A & 1999 & Competitive & Political & No \\
\hline 14 & Guping & Jiangxi & A & 1999 & Consensual & Political & Yes \\
\hline 15 & Hangbu & Jiangxi & A & 1999 & Noncompetitive & Social & No \\
\hline 16 & Hejiabao & Tianjin & I & 2000 & Competitive & None & No \\
\hline 17 & Hejiang & Jiangxi & A & 1999 & Noncompetitive & Political & No \\
\hline 18 & Highland Park & Zhejiang & I & 1995 & Consensual & Economic & Yes \\
\hline 19 & Houbu & Fujian & I & 1996 & Consensual & Political & Yes \\
\hline 20 & Hua & Jiangxi & A & 1999 & Noncompetitive & Political & No \\
\hline 21 & Huaxi & Zhejiang & I & 2002 & Consensual & Economic & Yes \\
\hline 22 & Jianfeng & Jiangxi & A & 1999 & Consensual & Social & Yes \\
\hline 23 & Kanxia & Jiangxi & A & 1999 & Consensual & Social & No \\
\hline 24 & Libei & Jiangxi & $\mathrm{A}$ & 1999 & Competitive & Social & No \\
\hline 25 & Lin & Shandong & $?$ & 2002 & Competitive & Political & No \\
\hline 26 & Lishu & Hubei & I & 1999 & Consensual & Economic & Yes \\
\hline
\end{tabular}


Table 1 Continued

\begin{tabular}{|c|c|c|c|c|c|c|c|}
\hline $\begin{array}{l}\text { Case } \\
\text { Number }\end{array}$ & Village & Province & Economy $^{\mathrm{a}}$ & $\begin{array}{l}\text { Year of } \\
\text { Election }\end{array}$ & $\begin{array}{l}\text { Nature of } \\
\text { Election }\end{array}$ & Elite & $\begin{array}{l}\text { Public } \\
\text { Goods }\end{array}$ \\
\hline 27 & Long & Inner Mongolia & A & 2000 & Noncompetitive & Political/economic & No \\
\hline 28 & Long Bridge & Zhejiang & A & 2001 & Competitive & None & No \\
\hline 29 & Luojia & Jiangxi & A & 1999 & Competitive & Social & No \\
\hline 30 & Makou & Jiangxi & A & 1999 & Consensual & Social & Yes \\
\hline 31 & Mao & Shaanxi & A & 1996 & Competitive & Social & No \\
\hline 32 & Nanmen & Jiangxi & A & 1999 & Consensual & Social & Yes \\
\hline 33 & Ping & Inner Mongolia & A & 2000 & Noncompetitive & Political & No \\
\hline 34 & Putian & Jiangxi & $\mathrm{I}$ & 1999 & Noncompetitive & Political & No \\
\hline 35 & Quchi & Jiangxi & A & 1999 & Competitive & Political/social & No \\
\hline 36 & Qudou & Jiangxi & A & 1999 & Competitive & Social & No \\
\hline 37 & Shangfu & Jiangxi & A & 1999 & Noncompetitive & Social & No \\
\hline 38 & Shangyang & Zhejiang & $\mathrm{I}$ & 2002 & Consensual & Economic & Yes \\
\hline 39 & Shiqian & Jiangxi & A & 1999 & Consensual & Social & Yes \\
\hline 40 & Shiqiao & Jiangxi & A & 1999 & Competitive & Social & No \\
\hline 41 & Taoyuan & Jiangxi & A & 1999 & Noncompetitive & Political & No \\
\hline 42 & Tie & Jiangxi & A & 1999 & Noncompetitive & Political & No \\
\hline 43 & Wangshatang & Jiangxi & A & 1999 & Noncompetitive & Political & No \\
\hline 44 & Wangyue & Hubei & A & 1999 & Competitive & Political & No \\
\hline 45 & Water Dragon & Guangdong & I & 2002 & Consensual & Political & Yes \\
\hline 46 & Water Wood & Hebei & A & 2002 & Consensual & Political & Yes \\
\hline
\end{tabular}


Table 1 Continued

\begin{tabular}{|c|c|c|c|c|c|c|c|}
\hline $\begin{array}{l}\text { Case } \\
\text { Number }\end{array}$ & Village & Province & Economy $^{\mathrm{a}}$ & $\begin{array}{l}\text { Year of } \\
\text { Election }\end{array}$ & $\begin{array}{l}\text { Nature of } \\
\text { Election }\end{array}$ & Elite & $\begin{array}{l}\text { Public } \\
\text { Goods }\end{array}$ \\
\hline 47 & Wufang & Jiangxi & A & 1999 & Noncompetitive & Political & No \\
\hline 48 & Wugezhuang & Shandong & A & 2002 & Competitive & Political & No \\
\hline 49 & Xialang & Zhejiang & I & 2002 & Competitive & Economic & No \\
\hline 50 & Xiawei & Jiangsu & I & 1999 & Competitive & None & Yes \\
\hline 51 & Xing & Inner Mongolia & A & 2000 & Consensual & Political & Yes \\
\hline 52 & Xinping & Jiangxi & A & 1999 & Noncompetitive & None & No \\
\hline 53 & Xiaoshui & Jiangxi & A & 1999 & Competitive & Social & No \\
\hline 54 & Xiyantou & Beijing & $?$ & 2004 & Competitive & Political & No \\
\hline 55 & Yongchang & Jiangxi & A & 1999 & Noncompetitive & Political/social & No \\
\hline 56 & You & Jiangxi & A & 1999 & Consensual & Social & Yes \\
\hline 57 & Zhong & Jiangxi & A & 1999 & Consensual & Social & Yes \\
\hline 58 & Zhong2 & Jiangxi & A & 1999 & Competitive & Social & No \\
\hline 59 & Zhou & Jiangxi & A & 1999 & Competitive & Political & No \\
\hline 60 & ? & Shaanxi & A & 1999 & Competitive & None & No \\
\hline 61 & ? & Shaanxi & A & 1999 & Competitive & Social & No \\
\hline 62 & ? & Shandong & I & 1999 & Consensual & ? & Yes \\
\hline
\end{tabular}

Sources: Ako (2003) for no. 4; Kennedy (2002) for nos. 60, 61; Lang (2003) for nos. 8, 21, 38; Li, Guo, and Xiao (2001) for nos. 9, 19, 22, 26, 39, 40, 41, 44, 50, 52, 53, 56, 59, 62; Tong (2002) for nos. 5, 27, 33, 51; Tong (2004) for nos. 27, 31, 33, 56; Xiao (2002) for nos. 2, 3, 14, 15, 20, 24, 32, 37, 43, 55, 58; Xiao, Qiu, and Tang (2001) for nos. 1, 6, 10, 12, 17, 23, 29, 30, 34, 35, 36, 42, 47, 57; Xu (2004) for nos. 11, 13, 16, 25, 48, 49, 54; interviewees (1, village cadre; 2-3, villagers: Guangdong, November 2004) for nos. 45; interviewees (12-13, 20, village cadre; 28-29, villagers: Hebei, January 2005) for nos.7, 46; interviewees (103, county official; 104-105, village cadres; 106-108, villagers: Zhejiang, December 2004) for nos. 18, 28.

Note: a. Economy: A = Agricultural; I = Industrialized. 
In the previous section I developed the argument that the VC cadres elected via consensual election provide public goods while those elected by a competitive election do not. Can we observe this tendency in other villages? In Table 1, I categorize the sixty-two village elections into three types: competitive, noncompetitive, and consensual. I categorize elections as competitive if the VC chief is elected separately from other $\mathrm{VC}$ members and the elected $\mathrm{VC}$ chief receives less than 70 percent of the votes. ${ }^{7}$ I categorize elections as competitive if the candidate who receives the most votes among the elected $\mathrm{VC}$ members will be VC chief and the votes for the elected VC member with the fewest votes are less than 70 percent of the eligible votes. ${ }^{8}$ I categorize the election as noncompetitive if the winner's vote is above 70 percent and the sources show no evidence that villagers reached a preelectoral consensus. Meanwhile, I categorize the election as consensual if the winner's vote is above 70 percent and the sources show that villagers reached a preelectoral consensus. Among the sixty-two cases, there are twenty-five competitive elections, sixteen noncompetitive elections, and twenty-one consensual elections.

In these sixty-two cases, we can observe the tendency that public goods will be provided if an election is consensual while they will not be provided if an election is competitive or noncompetitive. Table 2 shows that in this dataset, twenty out of the twenty-one consensual elections led to the provision of public goods by the VC, twenty-four out of the twenty-five competitive elections led to a poor provision of public goods by the $\mathrm{VC}$, and all the sixteen noncompetitive elections led to a poor provision of public goods. ${ }^{9}$

The anecdotes introduced in the last section suggest that villagers in industrialized villages can reach preelectoral consensus relatively easily on who has the intention and ability to provide public goods, while they find it difficult to reach such a consensus in agricultural villages. Can we observe this tendency in the sixty-two cases listed in Table 1? Table 3 categorizes the cases based on the villages' economic conditions (agricultural or industrialized), elite types (political, economic, social, or none), and the nature of the elections (competitive, noncompetitive, or consensual). Three cases are dropped from the original dataset of Table 1. In two cases (nos. 25 and 44), the sources do not specify whether the village is agricultural or industrialized, and I cannot obtain information about elite type in one case (no. 62).

Among the fifty-nine cases shown in Table 3, forty-eight are from agricultural villages and eleven are from industrialized villages. Thirteen of the forty-eight elections are consensual in agricultural 
Table 2 Nature of Elections and the Provision of Public Goods $(N=62)$



Note: Case numbers in parentheses.

villages and seven of the eleven elections are consensual in industrialized villages. Thus, we can observe that an election is more likely to be consensual in an industrialized village than in an agricultural village. In the seven industrialized villages that held a consensual election, villagers reached a preelectoral consensus on the economic elite's intention and ability to provide public goods in five villages.

Not surprisingly, none of the forty-eight agricultural villages had economic elites. In the thirteen agricultural villages that held a consensual election, villagers reached a preelectoral consensus on the political elites' intention and ability to provide public goods in five cases, on the social elites' in seven cases, and on the political and social elites' in one case. In the twenty-six cases where the political elites were involved in a village election (including the cases where the political elites were also considered the economic or social elites), an election was consensual and public goods were provided in six cases. In the twenty-eight cases where the social elites were involved in a village election, an election was consensual in eight cases and public goods were provided in seven cases.

Overall, while economic elites in industrialized villages provide public goods, political or social elites' involvement in rural politics in agricultural villages does not always lead to good governance. Of 
Table 3 Economy, Elites, and Consensual Elections $(N=59)$

\begin{tabular}{|c|c|c|c|c|c|c|c|}
\hline & Political & Economic & Social & $\begin{array}{l}\text { Political/ } \\
\text { Economic }\end{array}$ & $\begin{array}{l}\text { Political/ } \\
\text { Social }\end{array}$ & None & Total \\
\hline \multicolumn{8}{|l|}{ Agricultural } \\
\hline Competitive & $\begin{array}{c}7 \text { cases } \\
(4,10,11,13 \\
44,48,59)\end{array}$ & - & $\begin{array}{c}9 \text { cases } \\
(12,24,29,31,36 \\
40,53,58,61)\end{array}$ & - & $\begin{array}{c}3 \text { cases } \\
(9,28,35)\end{array}$ & $\begin{array}{l}1 \text { case } \\
(60)\end{array}$ & 20 cases \\
\hline Noncompetitive & $\begin{array}{c}8 \text { cases } \\
(6,17,20,33 \\
41,42,43,47)\end{array}$ & - & $\begin{array}{c}3 \text { cases } \\
(2,15,37)\end{array}$ & $\begin{array}{l}1 \text { case } \\
(27)\end{array}$ & $\begin{array}{l}1 \text { case } \\
(55)\end{array}$ & $\begin{array}{l}2 \text { cases } \\
(3,52)\end{array}$ & 15 cases \\
\hline Consensual & $\begin{array}{c}5 \text { cases } \\
(5,7,14,46,51)\end{array}$ & - & $\begin{array}{c}7 \text { cases } \\
(22,23,30,32 \\
39,56,57)\end{array}$ & - & $\begin{array}{l}1 \text { case } \\
(1)\end{array}$ & - & 13 cases \\
\hline Total & 20 cases & - & 19 cases & 1 case & 5 cases & 3 cases & 48 cases \\
\hline \multicolumn{8}{|l|}{ Industrialized } \\
\hline Competitive & - & $\begin{array}{l}1 \text { case } \\
(49)\end{array}$ & - & - & - & $\begin{array}{l}2 \text { cases } \\
(16,50)\end{array}$ & 3 cases \\
\hline Noncompetitive & $\begin{array}{l}1 \text { case } \\
(34)\end{array}$ & - & - & - & - & - & 1 case \\
\hline Consensual & $\begin{array}{l}2 \text { cases } \\
(19,45)\end{array}$ & $\begin{array}{c}5 \text { cases } \\
(8,18,21,26,38)\end{array}$ & - & - & - & - & 7 cases \\
\hline Total & 3 cases & 6 cases & - & - & - & 2 cases & 11 cases \\
\hline
\end{tabular}

Note: Case numbers in parentheses: 
the twenty-six cases where political elites were involved in rural politics in agricultural villages, villagers were dissatisfied with the provision of public goods in twenty of them. In these twenty villages, the VC cadres were elected by competitive elections in ten cases and by noncompetitive elections in ten cases. In these cases, political elites did not have the intention to serve the whole village and the result was a nonconsensual election. If political elites are successful in manipulating an election the result will be a noncompetitive election, while if a village-supported candidate can successfully compete with a VPB-backed candidate, the result will be a competitive election. Even if a village-supported candidate wins, political elites will nullify the electoral result and undermine the authority of the elected candidate. As a result, public goods will not be provided following a competitive or noncompetitive election in agricultural villages.

Among the twenty-four cases where social elites were involved in rural politics in agricultural villages, the village held a nonconsensual election and villagers were dissatisfied with the provision of public goods in sixteen cases. Twelve of the sixteen nonconsensual elections were competitive. In these cases, kinship leaders failed to solve historical conflicts between kinship groups in a village election, and competition among kinship groups led to intense electoral competition-and hence electoral corruption. As a result, the elected village cadres did not provide public goods to the whole village but instead provided private goods to their own kinship group.

In sum, the fifty-nine cases of village elections shown in Table 3 suggest that electoral quality and the provision of public goods depend on the village's economic conditions. Good governance by economic elites may emerge from consensual elections in industrialized villages. In the meantime, in agricultural villages where villagers usually cannot find economic elites, good governance will emerge if political or social elites succeed in reaching a preelectoral consensus on a competent candidate among the villagers.

\section{Implications}

The CCP leadership and officials claim that the main objective of introducing village elections is to get local leaders to provide public goods. If local governments fail to provide public goods to villagers in rural areas, it will be a crisis for the regime. I agree that the regime ceteris paribus has strong interests in having effective local leadership, 
with local governments' providing public goods and being responsive to popular preferences. However, if the regime's main objective for introducing elections is getting officials to be responsive and provide public goods, why has the regime not introduced elections to higher levels of government? In reality, the regime has been more active in introducing an institution for nonparty villagers to participate in electing party cadres at the village level than in spreading the experiment of popularly electing nonparty cadres at the township and county levels.

The CCP leadership and central officials often claim that elections should be introduced first at the village level-where residents are familiar with the cadres and their politics - because of their belief that voters should have a lot of information to make the right choice. My argument in this article disagrees with this claim. If voters and candidates have perfect information about each other, electoral contestation will negatively affect electoral outcomes unless voters have reached a preelectoral consensus about competent leadership. With perfect information, candidates may easily determine what private goods they can provide to each voter to buy votes. Survey research shows that voters appreciate clean elections and are dissatisfied with electoral corruption, that the implementation of clean elections strengthens the legitimacy and trust of the village cadres, and that villagers give the central government and the regime credit for introducing village elections (Kennedy 2002; Li 2003; Manion 1996, 2006). However, as long as elections are held only at the village level, candidates will not turn to policy-based, organized campaigning because the cost of vote buying is low in a small electorate. Thus, the authoritarian regime prefers corrupt grassroots elections to competitive elections at higher levels. In this sense, village elections are a democratic institution that may strengthen the legitimacy and popularity of the authoritarian regime without increasing the threat to regime survival.

I should note that my argument developed here is based on the assumption that the CCP would lose control over electoral outcomes once elections are held at higher levels. With other things equal, increasing the size of the electorate decreases incentives for competition through vote buying, because the cost of vote buying goes up as the size of the electorate goes up. As the cost of vote buying increases, candidates must instead compete through organizations and campaign promises to provide public goods to appeal to voters. The main inference to be drawn from this finding is that elections have 
not spread to higher levels because the CCP prefers grassroots elections. However, if the CCP is able to intervene in electoral processes and outcomes in some way, such as by influencing who runs for elections or vetoing elected candidates, it might not find those elections at higher levels so threatening. If elections are held at higher levels, the CCP would make every effort for CCP candidates to win the elections. However, it is more costly to introduce and then manage higher-level elections than to resist the introduction of elections at higher levels and discourage programmatic opposition.

Because higher-level elections are not institutionalized in China, the model's implication for what would happen if elections are introduced at township levels or higher is more suggestive than conclusive. We cannot examine empirically whether electoral competition at higher levels of government would increase the provision of public goods and make local officials more responsive to popular preferences. Nor can we examine empirically whether candidates in elections at higher levels would be less likely to buy votes and more likely to campaign for their policy proposals. Although we cannot give a conclusive answer to these questions, the model's implication counters what the CCP leadership and officials often claim about the functions of village elections. The model's equilibrium outcome implies that rather than village democracy's being an experiment that has failed to further reforms, it is self-limiting by design.

Hiroki Takeuchi is assistant professor of political science and fellow of the John Goodwin Tower Center for Political Studies at Southern Methodist University. His research interests include Chinese and Japanese politics, comparative political economy of authoritarian regimes, and political economy and international relations of East Asia, as well as applying game theory to political science. His recent publications include articles in Modern China, International Relations of Asia-Pacific, Japanese Journal of Political Science, and Journal of Chinese Political Science.

\section{Appendix: Formal Description and Solution to the Village Election Game}

\section{The Candidate's Choice of Strategies and Payoffs}

The matrix in Figure A1 shows the incentives affecting a candidate in a village election. The utility the candidate would gain from winning the election is denoted by $W(W>0)$. Each candidate has two strategies: buying votes $(B V)$ and not buying votes $(N B V)$. The cost of 
buying votes $(C)$ is the multiplication of the cost to buy one vote $(\beta)$ and the number of votes needed to buy $(V)$ (i.e., $C=\beta V$ ). Moreover, the number of votes needed to buy is positively associated with how much the candidate is behind the other candidate $(\rho)$ and the size of the electorate $(E)$ (i.e., $V=\rho E$ ). Therefore, the cost of buying votes can be written as:

$$
C=\beta \rho E
$$

Figure A1 Payoffs in Village Elections

\begin{tabular}{|c|c|c|}
\hline & & didate 2 \\
\hline & Buying votes $(B V)$ & Not buying votes $(N B V)$ \\
\hline & $(1-p) W-C_{2}$ & 0 \\
\hline Buying votes $(B V)$ & $p W-C_{1}$ & $W-C_{1}$ \\
\hline Candidate 1 & $W-C_{2}$ & $(1-p) W$ \\
\hline $\begin{array}{l}\text { Not buying votes } \\
(N B V)\end{array}$ & 0 & $p W$ \\
\hline
\end{tabular}

Note: $W=$ the candidate's utility gained by winning the election. $C_{1}=$ Candidate 1 's utility lost by buying votes. $p=$ the probability that Candidate 1 wins the election when both candidates take the same strategy. $C_{1}=\beta(A+\varphi(1-p)) E$ and $C_{2}=\beta(A+\varphi p) E: \beta=$ the cost to buy one vote; $E=$ the size of the electorate; $\varphi$ and $A$ are positive constant numbers.

How much Candidate 1 is behind Candidate 2 is positively associated with $2-p$ while how much Candidate 2 is behind Candidate 1 is positively associated with $p$ (i.e., $p_{1}=A+\varphi(1-p)$ and $\rho_{2}=A+\varphi p$ ) $(A>0$ and $\varphi>0)$. Thus, Candidate 1's and Candidate 2's costs of buying votes could be written respectively:

$$
\begin{aligned}
& C_{1}=\beta(A+\varphi(1-p)) E \\
& C_{2}=\beta(A+\varphi p) E
\end{aligned}
$$

In this model, rather than having players choose the number of votes to buy (or the amount of money to be spent on vote buying), the cost of buying votes $(C)$ is folded into a specific function: $C=\beta \rho E$ : where $\beta$ is the cost to buy one vote; $E$ is the size of the electorate; and $\rho$ is how much the candidate is behind the other candidate, which is hence inversely related to $p$. 
Solution to the Model

This analysis only examines the case of $0<p \leq 0.5$. Below, I write outcomes using the notation: (Candidate 1's strategy, Candidate 2's strategy). Figure A2 describes the equilibrium strategies of the two candidates as a set of thresholds along the continuum of possible circumstances.

Figure A2 The Equilibrium Strategies in the Game

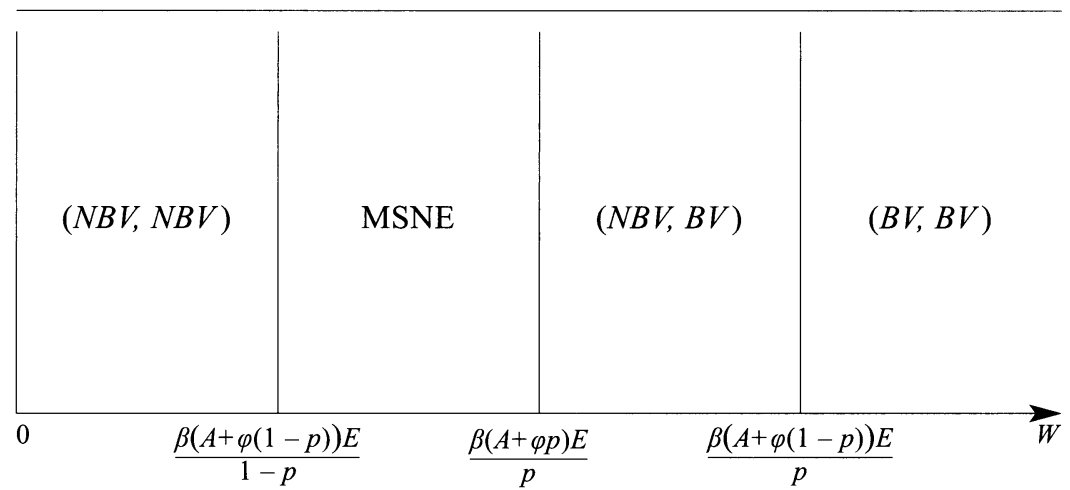

Notes: $(B V, B V)=$ both candidates buy votes. $(N B V, N B V)=$ neither candidate buys votes. $(N B V, B V)=$ Candidate 1 does not buy votes and Candidate 2 buys votes. MSNE $=$ each candidate buys votes with a certain probability.

Equilibrium 1. ( $B V, B V)$ will be a pure strategy Nash equilibrium (PSNE) if $p W-\beta(A+\varphi(1-p)) E \geq 0$ and $(1-p) W-\beta(A+\varphi p) E \geq 0$.

Thus, this PSNE will be sustained if $W \geq \frac{\beta(A+\varphi(1-p)) E}{p}$ and $W \geq \frac{\beta(A+\varphi p) E}{1-p}$. Because $\frac{\beta(A+\varphi(1-p)) E}{p} \geq \frac{\beta(A+\varphi p) E}{1-p}$ as long as $p \leq 0.5$, $(B V, B V)$ will be a PSNE if $W \geq \frac{\beta(A+\varphi(1-p)) E}{p}$.

Equilibrium 2. $(N B V, N B V)$ will be a PSNE if $p W \geq$ $W-\beta(A+\varphi(1-p)) E$ and $(1-p) W \geq W-\beta(A+\varphi p) E$. Thus, this PSNE will be sustained if $W \leq \frac{\beta(A+\varphi(1-p)) E}{1-p}$ and $W \leq \frac{\beta(A+\varphi p) E}{p}$. Because $\frac{\beta(A+\varphi p) E}{p} \geq \frac{\beta(A+\varphi(1-p)) E}{1-p},(N B V, N B V)$ will be a PSNE if $W \leq \frac{\beta(A+\varphi(1-p)) E}{1-p}$.

Equilibrium 3. ( $N B V, B V)$ will be a PSNE if $0 \geq p W-\beta(A+\varphi$ $(1-p)) E$ and $W-\beta(A+\varphi p) E \geq(1-p) W$. Thus, this PSNE will be 
sustained if $W \leq \frac{\beta(A+\varphi(1-p)) E}{p}$ and $W \geq \frac{\beta(A+\varphi p) E}{p}$. Because $\frac{\beta(A+\varphi(1-p)) E}{p} \geq \frac{\beta(A+\varphi p) E}{p},(N B V, B V)$ will be a PSNE if $\frac{\beta(A+\varphi(1-p)) E}{p}$ $\geq W \geq \frac{\beta(A+\varphi p) E}{p}$.

Equilibrium 4. No PSNE will exist but a mixed strategy Nash equilibrium (MSNE) will exist if $\frac{\beta(A+\varphi p) E}{p} \geq W \geq \frac{\beta(A+\varphi(1-p)) E}{1-p}$. At the MSNE: Candidate 1 will take $B V$ with the probability of $\frac{\beta(A+\varphi p) E-p W}{(1-2 p) W}$, and $N B V$ with $\frac{(1-p) W-\beta(A+\varphi p) E}{(1-2 p) W}$; and Candidate 2 will take $B V$ with the probability of $\frac{(1-p) W-\beta(A+\varphi(1-p)) E}{(1-2 p) W}$, and $N B V$ with $\frac{\beta(A+\varphi(1-p)) E-p W}{(1-2 p) W}$. Thus, at the MSNE, $(B V, B V)$ will occur with the probability of $\frac{(\beta(A+\varphi p) E-p W)((1-p) W-\beta(A+\varphi(1-p)) E)}{(1-2 p)^{2} W^{2}}$, $(N B V, N B V)$ with $\frac{((1-p) W-\beta(A+\varphi p) E)(\beta(A+\varphi(1-p)) E-p W)}{(1-2 p)^{2} w^{2}},(B V, N B V)$ with $\frac{(\beta(A+\varphi p) E-p W)(\beta(A+\varphi(1-p)) E-p W)}{(1-2 p)^{2} w^{2}}$, and $(N B V, B V)$ with $\frac{((1-p) W-\beta(A+\varphi p) E)((1-p) W-\beta(A+\varphi(1-p)) E)}{(1-2 p)^{2} w^{2}}$.

\section{Competition in Grassroots Election}

If $W \leq \frac{\beta(A+\varphi(1-p)) E}{1-p}$, then $(N B V, N B V)$ is a PSNE, and hence the probability of a vote-buying candidate's win is zero. If $\frac{\beta(A+\varphi(1-p)) E}{1-p} \leq W \leq \frac{\beta(A+\varphi p) E}{p}$, then at the MSNE the probability of a vote-buying candidate's win is $1-\frac{(\beta(A+\varphi p) E-p W)((1-p) W-\beta(A+\varphi(1-p)) E)}{\left.(1-2 p)^{2} W^{2}\right)}$; $\frac{\partial}{\partial W}\left(1-\frac{(\beta(A+\varphi p) E-p W)((1-p) W-\beta(A+\varphi(1-p)) E)}{\left.(1-2 p)^{2} w^{2}\right)}\right)<0$ if $W<$ $\frac{2 \beta(A+\varphi(1-p))(A+\varphi p) E}{(1-p)(A+\varphi(1-p))+p(A+\varphi p)} ; \frac{\partial}{\partial W}\left(1-\frac{(\beta(A+\varphi p) E-p W)((1-p) W-\beta(A+\varphi(1-p)) E)}{\left.(1-2 p)^{2} w^{2}\right)}\right)$ $>0$ if $W>\frac{2 \beta(A+\varphi(1-p))(A+\varphi p) E}{(1-p)(A+\varphi(1-p))+p(A+\varphi p)}$; and $\frac{\partial}{\partial W}\left(1-\frac{(\beta(A+\varphi p) E-p W)((1-p) W-\beta(A+\varphi(1-p)) E)}{\left.(1-2 p)^{2} w^{2}\right)}\right)=0$ if $W=$ $\frac{2 \beta(A+\varphi(1-p))(A+\varphi p) E}{(1-p)(A+\varphi(1-p))+p(A+\varphi p)}$, with which the probability of a votebuying candidate's win is at a local minimum. If $\frac{\beta(A+\varphi p) E}{p} \leq$ $W \leq \frac{\beta(A+\varphi(1-p)) E}{p}$, then $(N B V, B V)$ is a PSNE, and hence the probability of a vote-buying candidate's win is one. If 
$W \geq \frac{\beta(A+\varphi(1-p)) E}{p}$, then $(B V, B V)$ is a PSNE, and hence the probability of a vote-buying candidate's win is one.

\section{The Size of the Electorate}

If $E \leq \frac{p W}{\beta(A+\varphi(1-p))}$, then $(B V, B V)$ is a PSNE, and hence the probability of a vote-buying candidate's win is one. If $\frac{p W}{\beta(A+\varphi(1-p))} \leq E \leq \frac{p W}{\beta(A+\varphi p)}$, then $(N B V, B V)$ is a PSNE, and hence the probability of a corrupt candidate's win is one. If $\frac{p W}{\beta(A+\varphi p)} \leq E \leq \frac{(1-p) W}{\beta(A+\varphi(1-p))}$, then at the MSNE the probability of a vote-buying candidate's win is

$1-\frac{(\beta(A+\varphi \mathrm{p}) E-p W)((1-p) W-\beta(A+\varphi(1-p)) E)}{(1-2 p)^{2} w^{2}}<0$ if

$E<\frac{\beta(A+\varphi \mathrm{p}) p W+\beta)(A+\varphi(1-p))(1-p) W}{2 \beta^{2}(A+\varphi p)(A+\varphi(1-p))} ;$

$\frac{\partial}{\partial W}\left(1-\frac{(\beta(A+\varphi p) E-p W)((1-p) W-\beta(A+\varphi(1-p)) E)}{\left.(1-2 p)^{2} W^{2}\right)}\right)>0$ if $E>$ $\frac{(\beta(A+\varphi \mathrm{p}) p W+\beta)(A+\varphi(1-p))(1-p) W}{2 \beta^{2}(A+\varphi p)(A+\varphi(1-p))}$ and

$\frac{\partial}{\partial W}\left(1-\frac{(\beta(A+\varphi p) E-p W)((1-p) W-\dot{\beta}(A+\varphi(1-p)) E)}{\left.(1-2 p)^{2} w^{2}\right)}\right)=0$ if $E=\frac{(\beta(A+\varphi \mathrm{p}) p W+\beta)(A+\varphi(1-p))(1-p) W}{2 \beta^{2}(A+\varphi p)(A+\varphi(1-p))}$, with which the probability of a vote-buying candidate's win is at a local minimum. If $E \geq$ $\frac{(1-p) W}{\beta(A+\varphi(1-p))}$, then $(N B V, N B V)$ is a PSNE, and hence the probability of a vote-buying candidate's win is zero.

\section{Notes}

1. Kennedy (2010) points out that more vote-buying cases are reported as contested village elections spread in China.

2. The set of cases examined in this article is selected from my field interviews and previous studies of other scholars. Most of my field research on village politics was conducted in 2004-2005. I conducted field interviews with more than a hundred people in forty villages across seven of China's thirty-one provinces (Guangdong, Guizhou, Hebei, Hubei, Hunan, Jiangxi, and Zhejiang). The seven provinces include both rich industrialized villages in coastal regions (such as Guangdong and Zhejiang) and poor agricultural villages in inland regions (such as Guizhou, Hebei, Hubei, Hunan, and Jiangxi). The list of interviewees, cited by number throughout the article, and the interview questions are available from the author upon request. 
3. To keep the anonymity of my interviewees, I use fictitious names to describe the localities where I conducted interviews.

4. For comparative studies of when vote buying becomes an effective means, see Lehoucq (2007).

5. In Taiwan, where electorates are bigger than grassroots elections, candidates use vote brokers for vote buying to work (Rigger 1999).

6. Her sample does not include single-surname villages.

7. Note that I have defined a competitive election as one in which the race between candidates is so close that one cannot easily predict who will win and a contested election as one in which the number of candidates exceeds the number of seats available, though a number of previous studies on village elections use the latter definition to describe a competitive election. Because one of the key observations of village elections is that contested elections are not always competitive, and contested elections have spread throughout China, it makes more sense to measure the percentage of votes rather than the number of candidates to gauge the competitiveness of an election.

8. In this type of election, each voter can cast the same number of votes as the number of seats.

9. Note that because many of the cases are from the secondary literature, I cannot categorize the provision of public goods in a more systematic way. In many cases the judgment of whether public goods are provided is based on whether villagers are satisfied with the provision of public goods.

\section{References}

Ako, Tomoko. 2003. "Cong 'Shangfang' de 'Aimeixing' Kan Zhongguo Nongcun Shehui de Quanli, Liyi he Zhixu: Yi Nei Menggu Chishi Cun 'Shangfang' Yanjiu wei Li' [Rights, interests, and order of China's rural society seen from "ambiguity" of "petitioning": A case study of a "petitioning" in Chishi Village in Inner Mongolia]. In Zhongguo Nongcun Yanjiu 2002 Juan [Chinese rural studies 2002], ed. Xu Yong, 246-273. Beijing: Zhongguo Shehui Kexue Chubanshe.

Aldrich, John. 1995. Why Parties? The Origin and Transformation of Political Parties in America. Chicago: University of Chicago Press.

Alpermann, Bjorn. 2001. "The Post-election Administration of Chinese Villages." China Journal 46: 45-67.

Blaydes, Lisa. 2010. Elections and Distributive Politics in Mubarak's Egypt. New York: Cambridge University Press.

Bueno de Mesquita, Bruce, Alastair Smith, Randolph M. Silverson, and James D. Morrow. 2003. The Logic of Political Survival. Cambridge: MIT Press.

Chan, Sylvia. 1998. "Research Notes on Villagers' Committee Election: Chinese Style Democracy." Journal of Contemporary China 7, 19: 507-521.

Cox, Gary W. 1987. The Efficient Secret: The Cabinet and the Development of Political Parties in Victorian England. New York: Cambridge University Press. 
Gandhi, Jennifer, and Adam Przeworski. 2006. "Cooperation, Cooptation, and Rebellion Under Dictatorships." Economics and Politics 18, 1: 1-26.

Geddes, Barbara. 2006. "Why Parties and Elections in Authoritarian Regimes?" Manuscript, UCLA.

Groseclose, Tim. 2001. "A Model of Candidate Location When One Candidate Has a Valence Advantage." American Journal of Political Science 45, 4: 862-886.

Kelliher, Daniel. 1997. "The Chinese Debate over Village Self-Government." China Journal 37: 63-86.

Kennedy, John James. 2002. "The Fate of 'Grassroots Democracy' in Rural China: Real Versus Cosmetic Election.” Asian Survey 42, 3: 456-482.

- 2009. "Legitimacy with Chinese Characteristics: "Two Increases, One Reduction.'” Journal of Contemporary China 18, 60: 391-395.

- 2010. "The Price of Democracy: Vote Buying and Village Elections in China." Asian Politics and Policy 2, 4: 617-631.

Kennedy, John James, Scott Rozelle, and Yaojiang Shi. 2004. "Elected Leaders and Collective Land: Farmers' Evaluation of Village Leaders' Performance in Rural China." Journal of Chinese Political Science 9, 1: $1-22$.

Kousser, J. Morgan. 1974. The Shaping of Southern Politics: Suffrage Restriction and the Establishment of the One-Party South, 1880-1910. New Haven: Yale University Press.

Lang, Youxing. 2003. "Cong Jingji Jingying dao Zhengzhi Guanlizhe: Zhongguo Cunmin Xuanju yu Cunji Lingdao de Jiti" [From economic elites to political administrators: Village elections in China and succession of the village leadership]. In Zhongguo Nongcun Yanjiu 2002 Juan [Chinese rural studies 2002], ed. Xu Yong, 177-206. Beijing: Zhongguo Shehui Kexue Chubanshe.

Lehoucq, Fabrice. 2003. "Electoral Fraud: Causes, Types, and Consequences." Annual Review of Political Science 6: 233-256.

- 2007. "When Does a Market for Votes Emerge?" In Elections for Sale: The Causes and Consequences of Vote Buying, ed. Frederic Charles Schaffer, 33-45. Boulder, CO: Lynne Rienner Publishers.

Levitsky, Steven, and Lucan A. Way. 2002. "The Rise of Competitive Authoritarianism." Journal of Democracy 13, 2: 51-65.

Li, Lianjiang. 2001. "Elections and Popular Resistance in Rural China." China Information 15, 2: 1-19.

- 2003. "The Empowering Effect of Village Elections in China." Asian Survey 43, 4: 648-662.

Li, Lianjiang, Guo Zhenglin, and Xiao Tangbiao, eds. 2001. Cunweihui Xuanju Guancha [Survey on village elections]. Tianjin: Tianjin Renmin Chubanshe.

Li, Lianjiang, and Kevin J. O’Brien. 1999. “The Struggle over Village Elections." In The Paradox of China's Post-Mao Reforms, ed. Merle Goldman and Roderick MacFarquhar, 129-144. Cambridge: Harvard University Press. 
Liu, Yawei. 2000. "Consequences of Villager Committee Elections in China: Better Local Governance or More Consolidation of State Power?" China Perspectives 31: 19-35.

Louie, Kin-sheun. 2001. "Village Self-Governance and Democracy in China: An Evaluation." Democratization 8, 4: 134-154.

Lust-Okar, Ellen. 2005. Structuring Conflict in the Arab World: Incumbents, Opponents, and Institutions. New York: Cambridge University Press.

Magaloni, Beatriz. 2006. Voting for Autocracy: Hegemonic Party Survival and Its Demise in Mexico. New York: Cambridge University Press.

Magaloni, Beatriz, and Ruth Kricheli. 2010. "Political Order and One-Party Rule." Annual Review of Political Science 13: 123-143.

Manion, Melanie. 1996. "The Electoral Connection in the Chinese Countryside." American Political Science Review 90, 4: 736-748.

- 2006. "Democracy, Community, Trust: The Impact of Elections in Rural China." Comparative Political Studies 39, 3: 301-324.

Mozaffar, Shaheen. 2002. "Patterns of Electoral Governance in Africa's Emerging Democracies." International Political Science Review 23, 1: 85-101.

O'Brien, Kevin J., and Lianjiang Li. 2001. "Accommodating 'Democracy' in a One-Party State: Introducing Village Elections in China." In Elections and Democracy in Greater China, ed. Larry Diamond and Ramon H. Myers, 101-125. Oxford: Oxford University Press.

Pastor, Robert A., and Qingshan Tan. 2001. "The Meaning of China's Village Elections." In Elections and Democracy in Greater China, ed. Larry Diamond and Ramon H. Myers, 126-148. Oxford: Oxford University Press.

Pei, Minxin. 1995. "Creeping Democratization in China." Journal of Democracy 6, 4: 65-79.

Rigger, Shelley. 1999. Politics in Taiwan: Voting for Democracy. New York: Routledge.

Schatz, Edward. 2006. "Access by Accident: Legitimacy Claims and Democracy Promotion in Authoritarian Central Asia." International Political Science Review 27, 3: 263-284.

Schedler, Andreas. 2002. "The Menu of Manipulation." Journal of Democracy $13,2: 36-50$.

Schubert, Gunter, and Xuelian Chen. 2007. "Village Elections in Contemporary China: New Spaces for Generating Regime Legitimacy? Experiences from Lishu County." China Perspectives 3: 12-25.

Shi, Tianjian. 1999. "Village Committee Elections in China: Institutional Tactics for Democracy." World Politics 51, 3: 385-412.

Stokes, Susan C. 2007. "Is Vote Buying Undemocratic?" In Elections for Sale: The Causes and Consequences of Vote Buying, ed. Frederic Charles Schaffer, 81-99. Boulder, CO: Lynne Rienner Publishers.

Tan, Qingshan. 2009. "Building Democratic Infrastructure: Village Electoral Institutions.” Journal of Contemporary China 18, 60: 411-420. 
Tocqueville, Alexis de. [1835 and 1840] 2000. Democracy in America, trans. Harvey Mansfield and Delba Winthrop. Chicago: University of Chicago Press.

Tong, Zhihui. 2002. Xiangcun Guanxi Shiye zhong de Cunzhuang Xuanju: Yi Neimenggu Qiao Xiang Cunweihui Huanjie Xuanju Wei Gean [Village elections in the perspective of township-village relations: Case studies from village elections in Xiang Township in Inner Mongolia]. Xi'an: Xibei Daxue Chubanshe.

- 2004. Xuanju Shijian yu Cunzhuang Zhengzhi: Cunzhuang Shehui Guanlian zhong de Cunmin Xuanju [Elections and village politics: Village elections in networks in village society]. Beijing: Zhongguo Shehui Kexue Chubanshe.

Tsai, Lily L. 2007. "Solidary Groups, Informal Accountability, and Local Public Goods Provision in Rural China." American Political Science Review 101, 2: 355-372.

Xiao, Tangbiao, ed. 2002. Zongzu, Xiangcun Guanli yu Xuanju: Dui Jiangxi Sheng Shi-Er ge Cunweihui Xuanju de Guancha Yanjiu [Kinships, rural power, and elections: Studies on twelve village elections in Jiangxi Province]. Xi'an: Xibei Daxue Chubanshe.

Xiao, Tangbiao, Qiu Xinyou, and Tang Xiaoteng, eds. 2001. Duowei Shujiao zhong de Cunmin Zhixuan: Dui Shi-wu ge Cunweihui Xuanju de Guancha Yanjiu [Village elections from a multidimensional angle: Studies on fifteen village elections]. Beijing: Zhongguo Shehui Kexue Chubanshe.

$\mathrm{Xu}$, Fuqun. 2004. "Liangwei Maodun de Chuli: Anzhao Tongyi Jiepai Wudao" [How to solve the party-administration conflict: Dancing with the same rhythm]. Paper presented at the Third Conference on Constructing Rural Grassroots Organizations. Chinese University of Hong Kong. 


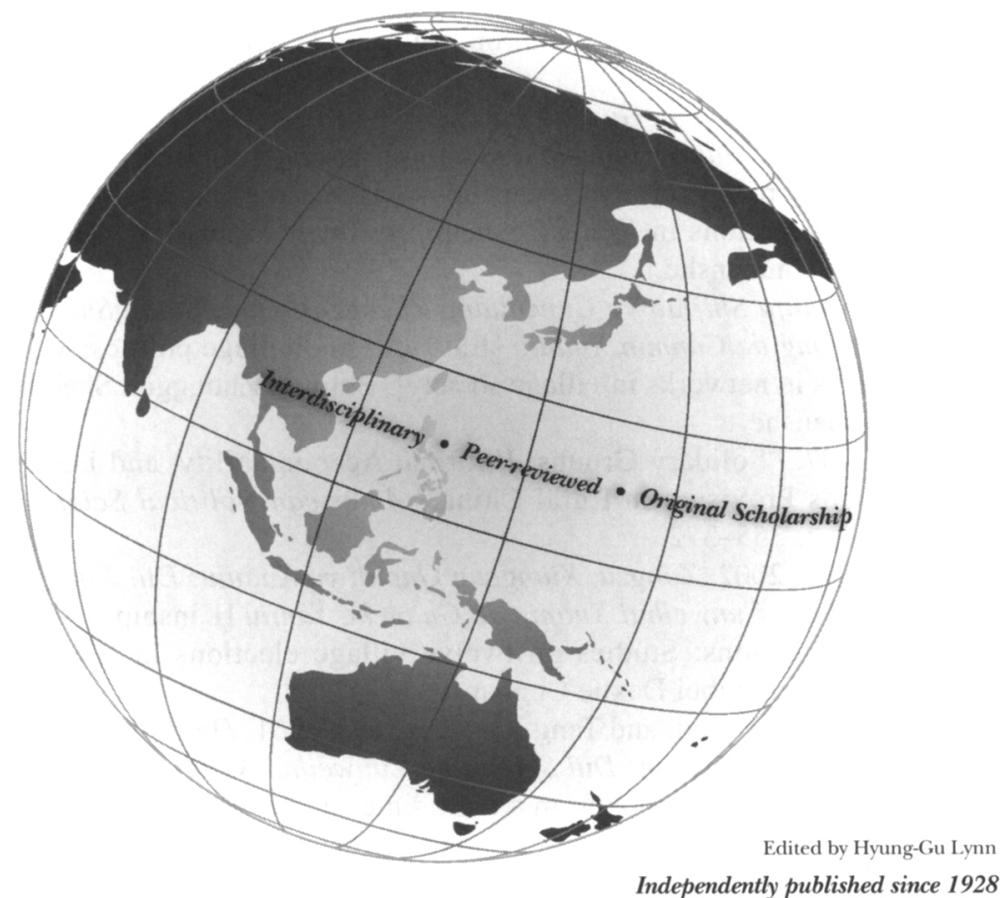

\section{Pacific Affairs An International Review of Asia and the Pacific}

There are few names among academic journals focused on Asia as rich in history and as evocative as Pacific Affairs. We explore contemporary issues that face a complex and interdependent Asia. Our international editorial board ensures articles are edited to the highest standard. Pacific Affairs' book reviews are a must for any busy scholar or librarian to keep abreast of the latest literature in the field.

Nostalgia, Anxiety and Hope: Migration and Ethnic Identity of Chosŏnjok in China by Wang-Bae KIm
The Elementary School Teacher, The Thug and His Grandmother: Informal Brokers and Transnational Migration from Indonesia by Heng Leng Chee, Brenda S.A. Yeoh and Thi Kieu Dung Vu
The Mobile Phone in India and Nepal:

Political Economy, Politics and Society by Robin Jeffrey and Assa Doron

\section{www.pacificaffairs.ubc.ca}

